type of crop, and location. Some exposures might be etiologically relevant, others might protect against lymphomas depending on age at first exposure, possibly in relation to the different type of immune response elicited.

\section{3e IS PAPER DUST IN SOFT TISSUE MILLS A PROBLEM?}

E Andersson. Occupational and Environmental Medicine, Sahlgrenska University Hospital, Göteborg, Sweden

\subsection{6/oemed-2018-ICOHabstracts. 1345}

More dust is generated in the production of soft tissue paper than in production of other paper products. In earlier days 10 and even up to $30 \mathrm{mg} / \mathrm{m}^{3}$ total dust was not unusual in this industry. We updated an earlier cohort of soft tissue mill workers and included more mills 2006. Inclusion criteria was $>1$ years work 1960-2006, 8353 were included, 40\% females. We did more dust measurements and obtained mill measurements and information on production changes. A millspecific job exposure matrix for paper dust was developed on department level and sometimes also job-specific. That allowed us to assess every mill year for each subject with an estimated mean level of total dust $\left(\mathrm{mg} / \mathrm{m}^{3}\right)$ into one of seven exposure categories. Our main exposure metric in this presentation is worked years with exposure to $>5 \mathrm{mg} / \mathrm{m}^{3}$ total dust. Those working from 1970 and alive 2007 got a questionnaire which $56 \%$ answered. As earlier studies on paper dust exposure and lung function have been inconclusive we made spirometry tests in one of the mills $(n=198)$. Every year exposed to $>5$ $\mathrm{mg} / \mathrm{m}^{3}$ total dust gave $0,9 \%$ loss in predicted $\mathrm{FEV} 1 \%$ and $0.6 \%$ loss in predicted FVC, a significantly decrease adjusted for pack-years, gender, atopy and body mass index compared to workers never exposed one year or more to $>5 \mathrm{mg} / \mathrm{m}^{3}$ total dust. Cohort mortality 1960-2013 has now been analysed compared to the general population in Sweden. Mortality in asthma and chronic obstructive pulmonary disease was increased in workers with $\geq 5$ years exposure to $>5 \mathrm{mg} / \mathrm{m}^{3}$ total dust both among males and females.

\section{USE, MISUSE, ABUSE OF PESTICIDE USE IN AGRICULTURE. WHICH INTERVENTIONS ARE NEEDED TO PROMOTE SAFETY AND HEALTH OF WORKERS?}

\footnotetext{
${ }^{1}$ Claudio Colosio, ${ }^{2}$ Gert van der Laan, ${ }^{1}$ Stefan Mandic-Rajicevic. 'Department of Health Sciences of the University of Milan and International Centre for Rural Health of the ASTT Saints Paolo and Carlo Hospital, Milan, Italy; ${ }^{2}$ Foundation Learning and Developing Occupational Health, PE Leusden, Netherlands
}

\subsection{6/oemed-2018-ICOHabstracts. 1346}

Aim of special session Pesticides are necessary in the modern agriculture and their use is unavoidable. However, very often misuse and abuse bring about unacceptable risk to agricultural workers and the environment. How to promote a safe us of these compounds? Worldwide known field experts will discuss this topic. Since it wil be a round table with an open discussion among speakers and of speakers with public, no title of presentation has been asked to the persons invited to contribute
Claudio Colosio ${ }^{1}$, Gert van der Laan $^{2}$, Stefan Mandic-Rajicevic $^{1}$, Erik Jors ${ }^{3}$, Andrea Rother ${ }^{4}$, Susan Brumby ${ }^{5}$, Shengli $\mathrm{Niu}^{6}$

${ }^{1}$ Department of Health Sciences of the University of Milan and International Centre for Rural Health of the S. Paolo Hospital, Italy

${ }^{2}$ Foundation Learning and Developing Occupational Health, PE Leusden, Netherlands

${ }^{3}$ Department of Occupational and Environmental Medicine, Odense University Hospital, Odense, Denmark

${ }^{4}$ Division of Environmental Health, School of Public Health and Family Medicine, University of Cape Town, Cape Town, South Africa

${ }^{5}$ National Centre for Farmer Health, Western District Health Service, Hamilton VIC Australia

${ }^{6}$ International Labour Organisation, Geneva, Switzerland

\section{$1663 a$ PESTICIDE POISONINGS ARE NOT RESTRICTED TO FARMERS AND VECTOR SPRAY-MEN!}

E Jørs. Department of Occupational and Environmental Medicine, Odense University Hospital, Odense, Denmark

\subsection{6/oemed-2018-ICOHabstracts.1347}

Acute pesticide poisonings are not restricted to professional users such as farmers and vector spray-men. The serious poisonings most often seen in health facilities are due to selfharm or accidental. Even consumers are in danger of suffering from both acute and chronic poisonings. In this presentation we focus on our findings from cross-sectional studies from Bolivia, Nepal and Uganda on pesticide poisonings due to self-harm, accidents and consumers eating pesticide residues in vegetables. Our findings shows that self-harm with pesticides are quite common and they are the poisonings most often seen in the hospitals. This is probably due to the easy access of very toxic pesticides sold in the streets and shops in most low-income countries. Female self-harm is more often seen among teen-agers, whereas males dominate the older age classes. Among children accidental poisonings predominates especially among boys. Consumers are in danger of chronic poisonings and diseases due to the consumption of pesticide residues in vegetables. Residue levels in tomato samples and other vegetables from Bolivia and Uganda are often shown to exceed the recommended maximum residue levels. This seems to be due to farmers spraying close to harvest or in some cases even after harvest to make the vegetables maintain themselves fresh for a longer period. In Uganda some consumers even says they prefer vegetables with pesticide stains on them, because then they think they are grown with modern agricultural methods and thus are healthier for consumers. To minimise pesticide exposure among professional pesticide users, consumers and others, awareness rising, training of users and banning of pesticides belonging to the WHO toxic class I and some class II is recommended. The access to pesticides in stores and at home should be restricted by only authorised selling pesticides and by locking up pesticides out of reach for children and others. These interventions has proven effective but are only implemented to a limited degree. 